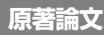

\section{発電ダム建設に伴う大井川の流況の変遷}

\author{
蔵治 光一郎 1)＼cjkstart溝口 隼平 1)2) \\ 1) 東京大学大学院農学生命科学研究科附属愛知演習林 \\ ( ( 489-0031 愛知県瀬戸市五位塚町11-44) \\ 2)リバーポリシーネットワーク \\ （テ550-0014 大阪市西区北堀江1-21-11-3B）
}

\begin{abstract}
かつて「越すに越されぬ大井川」とうたわれながら，戦後の発電ダム建設等により流量の大半を奪われ，下流の 一部で「河原砂漠」と化している大井川の流量変化の実態を明らかにするため，1923年から2000年までの流況の長 期変動について調べた，その結果，塩郷堰堤建設前の長期平均流況は平水 51.0 卜ン，低水 29.4 卜ン, 渇水 16.4 卜ンで

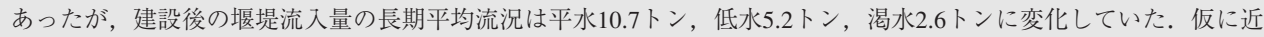
い将来，大井川の水量を回復するために塩郷堰堤を撤去したとしても，それだけでは下流の大井川に昭和 30 年代の 水量を取り戻すことはできず, 水量を取り戻したければ, 上流ダム群を含めた総合的な流量再生策を検討する必要 があることが示された.
\end{abstract}

キーワード : 流況, 大井川, 水力発電ダム, 河川流量再生, ダム撤去

\section{I 、はじめに}

大井川は幹線流路延長 $168 \mathrm{~km}$ (一級河川109水系 中16位), 流域面積 $1,280 \mathrm{~km}^{2}$ (51位) の河川である. 流域は幅に比べて約6倍の長さがあり，全流域中山 地が93\%を占める山地河川で，蛇行が激しい。年 降水量は中流域で $3,000 \mathrm{~mm}$ 超え，上流と下流にい くに従って減少するが, 最上流・最下流でも 2,000 mmを下回ることはなく, 多雨河川である。流 域人口は約 10 万人（76位）に過ぎず，全国的に見れ ば自然度の高い河川であるが，その実態は自然状態 からほど遠い。

現在の大井川は洪水時を除いて広大な河原にわず かに水が流れている姿が普通に見られるが，六れは 大井川に本来流れているべき水を人間が最上流から 最下流まで利用し尽くしているためである。塩郷堰 堤の下流では，1980年代のいわゆる「水返せ運動」 により灌溉期毎秒 5 トン $\left(=5 \mathrm{~m}^{3} / \mathrm{s}\right.$, 以下では単にト ンと記載）の水が流されるようになったが，川と平 行して埋められている電力会社の送水管の中には, その約18倍，86〜90トンの水を流す権利が設定され ている。つまりこの区間では，本来大井川を流れて
いるはずの水の $90 \%$ 以上は送水管の中に流せるよ うになっている。この水は発電だけでなく, 下流で 上水·工水・農水に振り分けられ, 隣の菊川流域の 末端まで水を届けている.

大井川には現在32のダム・堰堤が存在し，一部の ダムは上流側で土砂堆積・河床上昇・バックウォー ターの末端における洪水, 下流側で土砂供給不足に よる河床低下を起こして抢り，海岸では河川からの 土砂供給不足等による海岸線の後退が続いている. このような現在の大井川の姿は「死んだ川」と評さ れることもある。

本研究は，このような特徵をもつ大井川でこれま で観測された流量データを用いて, 過去の流況の変 化を振り返り，将来を展望することを目的とする。 なお, 本論文は「平成 17 年度静岡県戦略課題研究 『大井川・伊豆研究会』」の研究成果である.

\section{II 。用いたデータ}

我信省（現・経済産業省）は, 発電水力開発の基 礎資料として1910（明治43）年より発電水力調査を 
行い，全国各地の山地河川に測水所を設けて流量観 測を現在に至るまで続けている（蔵治，2001）。流 量観測データのうち, 各月, 各年の最大流量, 豊水 流量, 平水流量, 低水流量, 渴水流量, 最小流量と, これら各流量の $100 \mathrm{~km}^{2}$ 当たり比流量は, 1919 (大 正8）１957（昭和32）年まで「流量要覧」という名 称の冊子として公開されている（遞信省電氣局, 1933，電氣廳，1940，資源廳電力局，1950，通商産 業省公益事業局，1960)。豊水流量とは年間を通し て95日間はこれを下回らない流量（年間を通して 約 $25 \%$ の期間がこれを上回る流量），平水流量と は年間を通して185日間はこれを下回らない流量 (年間を通して約 $50 \%$ の期間がこれを上回る流量）， 低水流量とは年間を通して275日間はこれを下回ら ない流量（年間を通して $75 \%$ の期間がこれを上回る 流量), 渴水流量とは年間を通して355日間はこれを

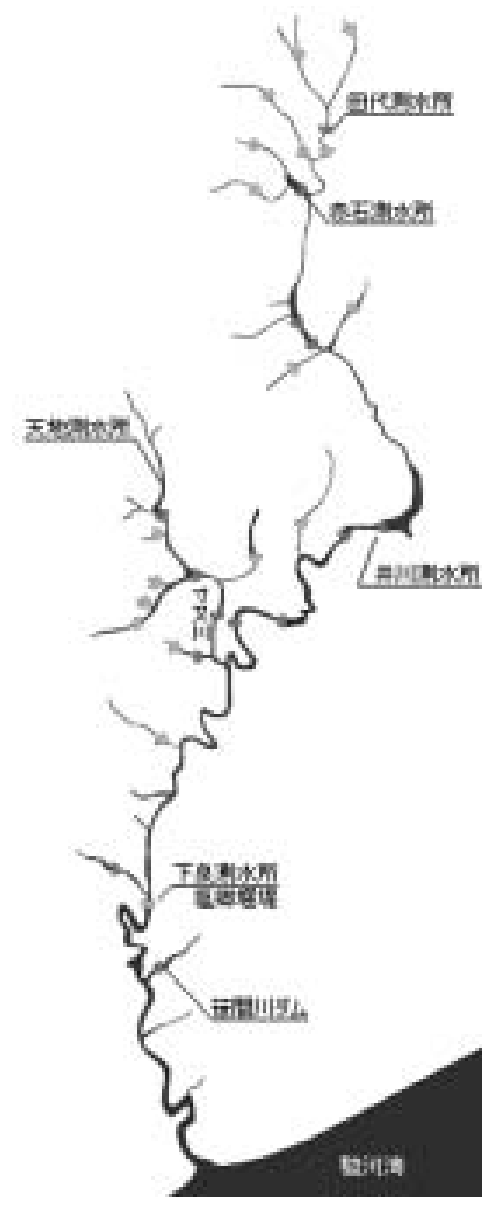

図-1 本研究で用いた測水所及びダムの位置

Fig.1 Location of discharge monitoring stations and dams.
下回らない流量（年間を通して $97 \%$ の期間がこれを 上回る流量) である.

1958（昭和33）年以降の流量要覧は公開されてい ないが，その一部が，国土調査法の規定に基づき国 土庁土地局国土調査課で行っている主要水系調査の 調査書に掲載されている. 大井川の場合は, 1988年 に調査が行われ, 『安倍川・大井川・菊川地域主要 水系調查書』（国土庁土地局国土調査課，1988）に その成果がまとめられている。

本研究では, この流量要覧抒よび調査書によって データが公開されている測水所のうち, 比較的長期 にデータが得られている5地点の流況デー夕, 及び,

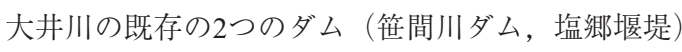
で観測された日単位の流入量データから作成した 流況デー夕を用いた。地点名, ダム名, 流域面積, デー夕使用可能期間を表一 1 , 各地点の位置を図一 1に示す.

\section{III. 結果と考察}

\section{1. 田代の流況}

田代測水所は, 大井川本流の最上流部に位置し, 流域面積は $108.0 \mathrm{~km}^{2}$ である. 東京電力 (株) が所有 する田代ダムの流域面積は $108.6 \mathrm{~km}^{2}$ であり, 測水所 が設定されたのは田代ダムの完成より後であること から, ダム貯水池の流入地点に設置された測水所で あると思われる。 (社) 電力土木技術協会（1995）に よれば，田代測水所は1926（大正15）年6月1日より 測定を開始し，測定義務者は1926（昭和元）年12月 31日まで東京電力, 1940（昭和15）年12月31日まで 東京電灯, 1950 (昭和25) 年12月31日まで日本発送 電, 以降, 東京電力となっている.

図一2は, 田代測水所に扔ける流況（豊水, 平水,

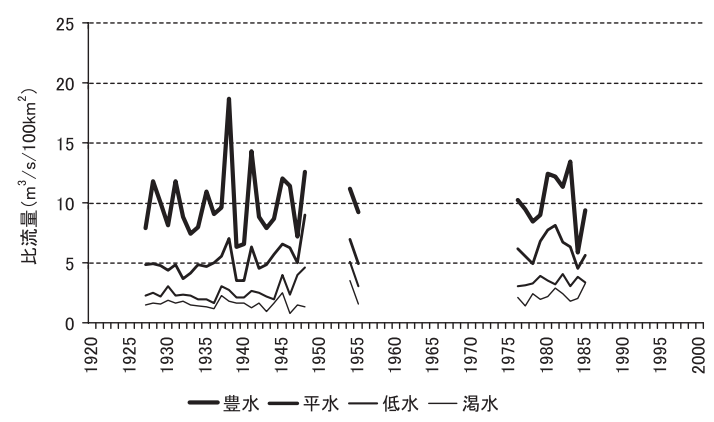

図-2 田代測水所における流況の長期変動

Fig.2 Long-term flow regime change in Tashiro. 
表一1 本研究に用いたデータ一覧

Table 1 Data used in this study.

\begin{tabular}{|c|c|c|c|c|c|c|}
\hline \multicolumn{2}{|c|}{ 測水所名 } & 田代 & 赤石 & 井川 & 下泉 & 天地 \\
\hline \multicolumn{2}{|c|}{ 流域面積 } & 108 & 240 & 447 & 959 & 73.4 \\
\hline & 年 & & & & & \\
\hline \multirow{7}{*}{$\begin{array}{l}\text { 第 } \\
\text { 资 } \\
\text { 流 } \\
\text { 量 } \\
\text { 要 }\end{array}$} & 1923 & $x$ & & $x$ & 0 & \\
\hline & 1924 & $\times$ & & $x$ & 0 & \\
\hline & 1925 & $\times$ & & $\times$ & $\bigcirc$ & \\
\hline & 1926 & $\times$ & & $\times$ & 0 & \\
\hline & 1927 & $\bigcirc$ & & $\bigcirc$ & 0 & \\
\hline & 1928 & 0 & & 0 & 0 & \\
\hline & 1929 & 0 & & 0 & 0 & \\
\hline \multirow{8}{*}{$\begin{array}{l}\text { 第 } \\
2 \\
\text { 咨 } \\
\text { 流 } \\
\text { 量 } \\
\text { 䚈 }\end{array}$} & 1930 & $\bigcirc$ & & 0 & $\bigcirc$ & $x$ \\
\hline & 1931 & 0 & & 0 & 0 & $\times$ \\
\hline & 1932 & 0 & & 0 & 0 & $\times$ \\
\hline & 1933 & $\bigcirc$ & & $\bigcirc$ & 0 & $\times$ \\
\hline & 1934 & 0 & & 0 & 0 & $\times$ \\
\hline & 1935 & $\bigcirc$ & & 0 & 0 & $\times$ \\
\hline & 1936 & $\bigcirc$ & & 0 & 0 & 0 \\
\hline & 1937 & 0 & & 0 & 0 & 0 \\
\hline \multirow{10}{*}{$\begin{array}{l}\text { 第 } \\
3 \\
\text { 次 } \\
\text { 流 } \\
\text { 量 } \\
\text { 要 }\end{array}$} & 1938 & $\bigcirc$ & & 0 & 0 & 0 \\
\hline & 1939 & 0 & & 0 & 0 & 0 \\
\hline & 1940 & 0 & & 0 & 0 & 0 \\
\hline & 1941 & $\bigcirc$ & & 0 & 0 & $\bigcirc$ \\
\hline & 1942 & 0 & & 0 & 0 & 0 \\
\hline & 1943 & $\bigcirc$ & & $\times$ & $\bigcirc$ & $\times$ \\
\hline & 1944 & $\bigcirc$ & & $x$ & $\times$ & 0 \\
\hline & 1945 & 0 & & $\times$ & 0 & 0 \\
\hline & 1946 & $\bigcirc$ & & $x$ & 0 & $\bigcirc$ \\
\hline & 1947 & 0 & & $x$ & 0 & 0 \\
\hline \multirow{10}{*}{$\begin{array}{l}\text { 第 } \\
4 \\
\text { 次 } \\
\text { 流 } \\
\text { 量 } \\
\text { 覽 }\end{array}$} & 1948 & 0 & $\times$ & 0 & 0 & $\times$ \\
\hline & 1949 & $\times$ & $x$ & $\bigcirc$ & $\bigcirc$ & 0 \\
\hline & 1950 & O & $x$ & 0 & 0 & 0 \\
\hline & 1951 & $\times$ & $x$ & 0 & 0 & $\times$ \\
\hline & 1952 & $\times$ & $\times$ & 0 & 0 & $\bigcirc$ \\
\hline & 1953 & $\times$ & $\times$ & 0 & 0 & 0 \\
\hline & 1954 & 0 & $\times$ & 0 & 0 & $\bigcirc$ \\
\hline & 1955 & 0 & $\times$ & 0 & 0 & 0 \\
\hline & 1956 & $\times$ & 0 & $x$ & 0 & 0 \\
\hline & 1957 & $\times$ & $\times$ & $\times$ & 0 & 0 \\
\hline \multirow{5}{*}{$\begin{array}{l}\text { 主 } \\
\text { 要 } \\
\text { 系 } \\
\text { 調 } \\
\text { 查 } \\
\text { 畫 }\end{array}$} & 1958 & $\times$ & $\times$ & & & $\times$ \\
\hline & 1959 & $\times$ & 0 & & & $\times$ \\
\hline & 1960 & $\times$ & 0 & & & $\triangle$ \\
\hline & 1961 & $\times$ & 0 & & & 0 \\
\hline & 1962 & $\times$ & 0 & & & 0 \\
\hline
\end{tabular}

\begin{tabular}{|c|c|c|c|c|c|c|c|}
\hline & 水 & & 田代 & 赤石 & 下泉 & 天地 & \\
\hline 流士 & 面皘 & $\left(\mathrm{km}^{2}\right)$ & 108 & 240 & 959 & 73.4 & \\
\hline & & 么名 & & & $\begin{array}{l}\text { 塩郷 } \\
\text { 堰堤 }\end{array}$ & & $\begin{array}{c}\text { 箅間川 } \\
\text { ダム }\end{array}$ \\
\hline & & 或面積 & & & 958 & & 68 \\
\hline & & 1963 & $\times$ & 0 & 0 & 0 & 0 \\
\hline & & 1964 & $\times$ & 0 & 0 & 0 & 0 \\
\hline & & 1965 & $\times$ & 0 & 0 & 0 & 0 \\
\hline & & 1966 & $\times$ & 0 & 0 & 0 & 0 \\
\hline & & 1967 & $\times$ & 0 & 0 & 0 & 0 \\
\hline & & 1968 & $\times$ & $\triangle$ & 0 & 0 & 0 \\
\hline & & 1969 & $\times$ & $\triangle$ & 0 & 0 & 0 \\
\hline & & 1970 & $\times$ & 0 & 0 & 0 & 0 \\
\hline & & 1971 & $\times$ & 0 & 0 & 0 & - \\
\hline & & 1972 & $\times$ & 0 & 0 & $\triangle$ & 0 \\
\hline 主 & & 1973 & $\times$ & 0 & 0 & 0 & 0 \\
\hline 永 & & 1974 & $\times$ & 0 & 0 & 0 & 0 \\
\hline $\begin{array}{l}\text { 采 } \\
\text { 調 }\end{array}$ & & 1975 & $\times$ & 0 & 0 & 0 & 0 \\
\hline $\begin{array}{l}\text { 查 } \\
\text { 書 }\end{array}$ & & 1976 & 0 & 0 & 0 & $\triangle$ & 0 \\
\hline & & 1977 & 0 & 0 & 0 & 0 & 0 \\
\hline & & 1978 & 0 & 0 & 0 & 0 & 0 \\
\hline & & 1979 & 0 & 0 & 0 & 0 & 0 \\
\hline & & 1980 & 0 & 0 & 0 & 0 & 0 \\
\hline & & 1981 & 0 & 0 & 0 & 0 & 0 \\
\hline & 名 & 1982 & 0 & 0 & 0 & $\triangle$ & 0 \\
\hline & $\bar{\xi}$ & 1983 & 0 & 0 & 0 & 0 & 0 \\
\hline & 夕 & 1984 & 0 & 0 & 0 & 0 & 0 \\
\hline & & 1985 & 0 & 0 & 0 & 0 & 0 \\
\hline & & 1986 & & & 0 & & ○ \\
\hline & & 1987 & & & 0 & & 0 \\
\hline & & 1988 & & & 0 & & - \\
\hline & & 1989 & & & 0 & & 0 \\
\hline & & 1990 & & & 0 & & 0 \\
\hline & & 1991 & & & 0 & & 0 \\
\hline & & 1992 & & & 0 & & 0 \\
\hline & & 1993 & & & 0 & & 0 \\
\hline & & 1994 & & & 0 & & 0 \\
\hline & & 1995 & & & 0 & & 0 \\
\hline & & 1996 & & & 0 & & 0 \\
\hline & & 1997 & & & 0 & & 0 \\
\hline & & 1998 & & & 0 & & 0 \\
\hline & & 1999 & & & 0 & & 0 \\
\hline & & 2000 & & & 0 & & 0 \\
\hline
\end{tabular}

遞信省電氣局 (1933), 電氣廳 (1940), 資源廳電力局 (1950), 通商産業省公益事業局 (1960), 国土庁土地局 国土調査課 (1988)をもとに作成

$\bigcirc \triangle \times$ は測水所のデータ, ○はダムのデータ

$\bigcirc=$ 年最大, 豊水, 平水, 低水, 渇水, 最小, 年平均のデー夕が揃って公開されている年

$\triangle=$ 年最大, 豊水, 平水, 低水, 渴水, 最小, 年平均のデー夕の一部が公開されている年

X=測定されていない,または,データが公開されていない年 
低水, 渇水) の1925８5（大正14～昭和60）年の61 年間長期変動を示している。戦前と1970～80（昭和 45～55）年代を比べると, 豊水流量にはさほど変化 がない一方で, 平水, 低水, 渇水流量は増加してい るように見える。1938（昭和13），1941（昭和16）年 には豊水, 平水流量が非常に多い。逆に少ないのは 1939，40（昭和14，15），1984（昭和59）年である.

田代測水所の上流にはその後, 西俣, 東俣の $2 つ$ の堰堤が建設され, 中部電力の二軒小屋発電所が 1995 (平成7）年6月より運転を開始している。二軒 小屋発電所は発電に使った水を全量川に戻している ため, 総水量には変動がないが, 流量は平準化され るため, 低水, 渇水流量が増加することが考えられ る。しかし堰堤工事が開始されたのは1985（昭和60） 年よりも後であるため，1970～80（昭和45～55）年 代の増加の原因とはならない.

田代ダムは, 標高約 $1,400 \mathrm{~m}$ 地点, 二軒小屋のわ ずかに上流に作られた高さ $17.3 \mathrm{~m}$, 有効貯水量 15 万 3 千 $\mathrm{m}^{3}$ の重力式ダムであり，1927（昭和2）年に完 成した。ここで貯水された水は伝付峠（標高 $2,049 \mathrm{~m})$ の下を通る長さ $5,236 \mathrm{~m}$ の圧力隧道で大井 川水系から富士川水系へ抜かれ, 田代川第2発電所 (1928（昭和3）年11月運転開始, 最大認可出力 $22,700 \mathrm{~kW})$ に送られている.

この発電事業は1908（明治41）年, 日英水電（株） のイギリス人技師アルバート・クレーン, ジェーム ス・スカイラーの 2 人によって実地踏査されて出来 た槻島（さわらじま）・保村計画の変形として計画 された。当初の水利権は毎秒2.92 トンであったが, 1955 （昭和30）年の更新の際に4.99トンに増やされ て現在に至っている (大井川の清流を守る研究協議 会・大井川環境保全推進協議会, 2004).

このダムは大井川の水を流域の外に流してしまう ため, 大井川の水量復活を求める住民や行政からは 批判の的となっており, 1975 (昭和50) 年12月の水 利権更新の際には山本県知事が地元の要望に応えて 東京電力に「取水量のうち2トンを大井川へ流して ほしい」と要求した。環境回復を揭げて水を返せと 自治体が国と電力会社に要求したのは恐らくこれが 全国で初めてである(静岡地理教育研究会編, 1989). それに対して東京電力は「水利権は半永久的なもの で，既権益が更改をきっかけになくなってしまうも のとは考えない. エネルギー危機時代の資源として の水を考え直すべきで, 流量確保の問題だけを考え るのは単純すぎるのではないか」と主張した.
2005 (平成17）年に田代ダムは30年ぶりの水利権 更新を迎えた。放流量を巡る東京電力と下流自治体 の協議は平行線であったため, 川根町内会長・区長 連絡協議会は大井川に清流を取り戻したいという趣 旨の署名活動を展開した。6月18日には大井川水シ ンポジウム「取り戻そう! 大井川の清流！」が開か れ, 田代名么の水利権更新に向けて, 地元案を東電 側に受け入れてもらうよう要望する大会宣言を採択 した。 その結果, 9月16日の第7回大井川水利流量調 整協議会において，県が新たにダム下流へ流す流量 の案を示した。県が示した案は, (1)河川利用, (2)動 植物のせい息, (3)景観の3つの観点から，1〜2月は 毎秒 0.8 トン，3４月に毎秒1トン，5１0月の雨の 多い季節で毎秒 2 トン，11〜 12月が毎秒1.1トンとい うものである.

この案に対し地元は歓迎の意向を示したが, 東京 電力は受け入れなかった。 10 月22日には「大井川の 環境を守る緊急大会」が流域各市町などから約 300 人が参加して川根本町の山村開発センターで開かれ た. 10 月 25 日の第 8 回協議会では, 東京電力が取水 を控える水量の数值を提案したが, 地元の要望は満 たされず，協議はさらに持ち越された。11月 8 日の 第9回協議会で東京電力は, 前回示した放流量から 大きく上乗せした数值を示したが，地元側とは合意 に至らなかった。そして遂に，11月21日に石川静岡 県知事は東京電力本社に白川進副社長を訪ね, 地元 側の希望に歩み寄った放流量を検討するよう求め た。その結果，11月28日の第10回協議会で，東京電 力と川根本町など流域自治体は合意に達した。12月 21日には, 取り決められた 0.43 卜ンを東電が試験放 流すると発表し，それを受けて当面の間，同量を下 流の中部電力の 5 ダムと国交省の長島ダムから放流 することで合意した。

\section{2. 赤石の流況}

赤石測水所は, 正確な位置は把握できないが, 大 井川本流の田代測水所の下流, 赤石沢川との合流地 点より少し下流に位置すると思われる。(社) 電力 土木技術協会（1995）によれば，1956（昭和31）年 1月1日に中部電力の測水所となったが, 赤石ダム建 設により 1989 (平成元) 年12月31日で観測を終了 した。

赤石測水所の上流で, 田代ダムより下流, および 支流には, 木賊堰堤 (本流, 流域面積 $133.4 \mathrm{~km}^{2}$ ), 奥西河内堰堤 (奥西河内, $16.5 \mathrm{~km}^{2}$ ), 滝見堰堤 (奥 


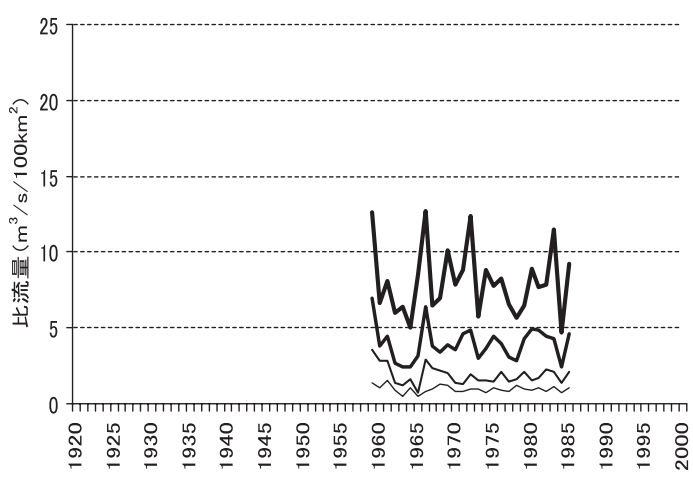

一豊水一平水一低水一渴水

図-3 赤石測水所における流況の長期変動

Fig.3 Long-term flow regime change in Akaishi.

西河内, $21.6 \mathrm{~km}^{2}$ ), 赤石沢堰堤 (赤石沢, $19.9 \mathrm{~km}^{2}$ ), 聖沢堰堤 $\left(8.3 \mathrm{~km}^{2}\right)$ が存在する。これらの堰堤で 集められた水は, 最終的に赤石ダム（赤石沢, $\left.47.0 \mathrm{~km}^{2}\right)$ に集約され, 本流の赤石測水所の横を通 る導水管により赤石発電所に送られ, その水利権は 毎秒28トンである。

赤石測水所で観測された流況の長期変動を図一3 に示す.変動には特に大きなトレンドはみられない。 1984（昭和59）年には豊水, 平水流量が少ないが, これは田代測水所と共通した特徵である。

現在は, 赤石ダムから赤石発電所に送水パイプで 水が抜かれているので, 流況は著しく変化したと思 われる。

\section{3. 井川の流況}

井川測水所は，（社）電力土木技術協会（1995）に 記載されていないが，井川ダム（流域面積 $459.3 \mathrm{~km}^{2}$ ) が現在存在しているところに位置していたと推測さ れる。井川ダムは1957（昭和32）年9月に運転を開始 している.

井川測水所で観測された流況の長期変動を図一4に 示す。変動には特に大きなトレンドはみられない. 1938（昭和13）年及び1941（昭和16）年には豊水,

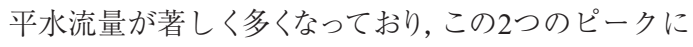
挟まれた1939，40（昭和14，15）年には特に少ない が，これは田代測水所のデー夕にも現われている。

\section{4. 下泉・塩郷堰堤の流況}

1) 下泉測水所（塩郷堰堤建設前）の流況

下泉測水所は, (社) 電力土木技術協会（1995）に 記載されていないが, 大井川本流の全幅横断堰堤で

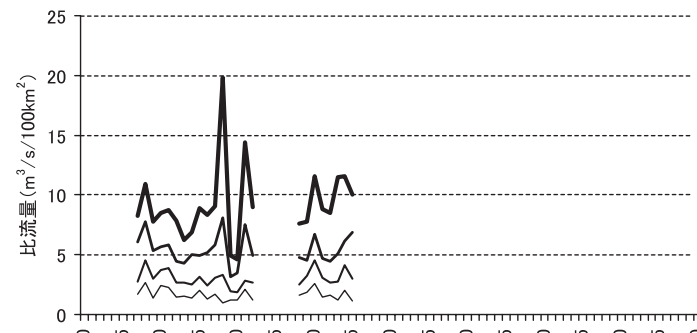

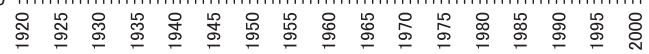

一豊水一平水一低水一渴水

図-4 井川測水所における流況の長期変動

Fig.4 Long-term flow regime change in Ikawa.

ある塩郷堰堤（流域面積 $957.8 \mathrm{~km}^{2}$ ) と流域面積がほ ぼ同じであることから，塩郷堰堤の位置にあったと みなしてよい。そこで塩郷堰堤と下泉測水所で観測 された流況データをあわせて図一5に示す。塩郷堰堤 建設前の下泉測水所における流況の長期変動（図一 5左半分）には, 田代, 井川の両測水所でみられた傾 向がそのまま示されている。すなわち，1938（昭和 13）年及び1941（昭和16）年には豊水, 平水流量が 著しく多くなっており，この2つのピークに挟まれた 1939，40（昭和14，15）年には特に少ない. 各流量 には, 増加又は減少の傾向はみられない。

1960（昭和35）年に完成した塩郷堰堤は, 以下の 3つの機能を持っている.

(1) 久野脇発電所で用いた水をサイホンで対岸の笹間 川ダムに送水する機能. ダム直下に巨大な送水管 が通っている．この管の中には久野脇発電所の水 利権である78トンの水を流すことができる.

(2) 本流の水をせき止めて取水し, 同じく笹間川ダ 厶に送る機能. 塩郷堰堤は大井川本流の河道全 幅の横断堰堤であり, 水利権量は39トンである.

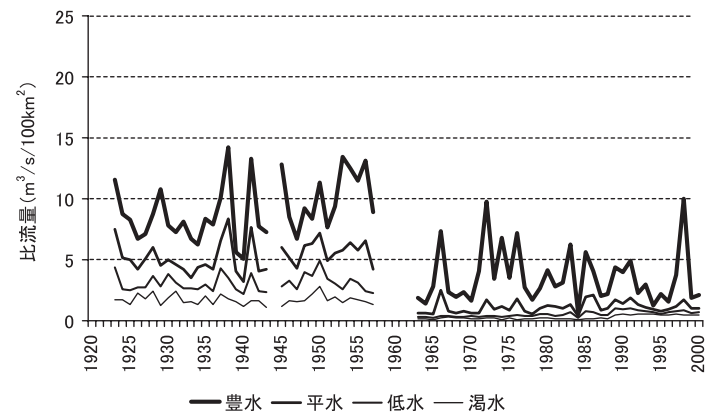

図－5 下泉測水所 - 塩郷堰堤における流況の長期変動 Fig.5 Long-term flow regime change in Shimoizumi (192357) and Shiogo Dam (1963-2000). 
(3) 久野脇から塩郷に渡る自動車の通れる橋, 生活 道路としての機能. 塩郷堰堤ができる前は吊り 橋であり，堰堤が出来て自動車が通ったときは 大変な喜びであったという。

一方，塩郷堰堤が完成した後に，下流では川口発 電所までの $22 \mathrm{~km} の$ 間, 堰堤が放流しない期間は支 流からの流入を除きほとんど水が流れない「河原砂 漠」と化し, 淡水魚類ほか生態系の激変, 砂塵, 気 温上昇, 川霧の消滅による茶の品質低下などの悪影 響が顕在化し, 上流では河床上昇に伴う水害が頻発 するようになった，塩郷堰堤完成前 15 年間と後 15 年 間を比較すると, 水害の発生回数は8回から14回に, 流出・埋没家屋数は 3 戸から 11 戸へ, 床上浸水は 47 戸から119戸，道路決壊は63箇所から140箇所へ，支 流堤防の決壊は2箇所から34箇所へそれぞれ増大し ている(静岡地理教育研究会編 (1989).

1975（昭和50）年には前述した山本知事が最上流 の田代ダム水利権更新時に合わせて「井川ダムから 川口発電所までの約 $80 \mathrm{~km}$ に水を返してほしい」と 要求し, 中部電力は「長島ダム完成後は, 維持流量 として1トンの水を塩郷堰堤から放流する」ことを 知事と合意した。これは1977（昭和52）年の「長島 ダム完成までの間は, 4 11月まで毎秒 0.5 トンを塩 郷堰堤より放流」するという暫定措置に生かされ, 住民要求実現の第一歩であった（静岡地理教育研究 会編, 1989).

1980（昭和55）年代初めからは，いわゆる「水返 せ」運動が台頭する。1988〜89（昭和63〜平成元） 年に大井川の18のダム・堰堤に関係する7つの発電 所の水利権が一斉に更新時期を迎えるのを控え， 80 年代初めから運動が芽生え始め, それに対応する形 で1985（昭和60）年に建設省（当時）主導で「大井 川中流域検討会」が設立された。その後様々な運動 や交渉を経て，5トン（3月20日～12月5日以外は3卜 ン）の維持流量が放流されるようになり, 斉藤茂滋 与史知事の短歌「桜花 5 卜ンの水に 照りはえて 大いなる川よみがえりたり」が塩郷堰堤を望む清 流公園の歌碑に刻まれるに至った。この間の経緯は, 静岡地理教育研究会編 (1989), 田淵 (2002), 天野 （2005）などに詳しい.

塩郷堰堤下流の大井川本流に5（3）トンの水が流 されるようになったが, その一方で川と平行して敷 設された送水管の中には, 塩郷堰堤〜笹間川ダム 86 トン，笹間川ダム〜川口発電所 90 トンの水を流す権 利が設定されており, 塩郷堰堤下流では依然として,
本来川に流れるはずの水の $90 \%$ 以上を送水管に流 してもよいことになっている。 そのため, 1998 (平 成10）年4月に結成された「大井川環境保全推進協 議会」や「大井川の清流を守る研究協議会」が塩郷 堰堤の撤去を含め, 現在でも活発に活動を続けてい る(大井川の清流を守る研究協議会・大井川環境保 全推進協議会, 2004).

図一5左半分に示したデー夕を単純に平均し, 塩郷 堰堤の流域面積を乗じて実流量に変換すると, 平水 51.0 トン, 低水 29.4 トン, 渇水 16.4 トンとなる. 斉藤 知事が勝ち取った 5 トンや3トンという数字は, 1982 年に建設省 (当時), 資源エネルギー庁, 電気事業連 合会で策定された「指針」(=流域面積 $100 \mathrm{~km}^{2}$ あた り 0.1 ～ 0.3 トンの維持用水）を若干上回ってはいると はいえ, 大井川を塩郷堰堤が存在する以前の姿に戻 そうとした場合は，極めて不十分な流量でしかない ことがわかる。もし，大井川を以前の姿に戻そうと した場合，一年のうち75％は29トン，97％は16トン もの水を流す必要がある。

\section{2) 塩郷堰堤の流況}

現在, 塩郷堰堤が存在している地点は, 当時に比 べて現在は上流にたくさんのダムや堰堤が出来てい るため, 図一5の左半分に示された流況と, もし塩 郷堰堤を現在撤去した場合に生じうる流況とは異な っている可能性が高い。そこで，塩郷堰堤で観測さ れた流入量デー夕を用いて, 仮に上流ダム群はその ままで塩郷堰堤のみが撤去された場合, どのような 流況になるのかについて検討した.

図一5の右半分に示された塩郷堰堤建設後の堰堤流 入量の流況は, 建設前と比べて顕著に減少している. また他の測水所デー夕にも見られたように，1984 (昭和59) 年の豊水, 平水流量も非常に少なくなって いる. 1990年代には渇水流量がわずかながら増加し て扔り，1994 (平成6）年 (平6渴水) の流量も 1984 （昭和59）年ほど小さくはない.

塩郷堰堤建設後, 1963 2000年の平水, 低水, 渇 水流量を各年ごとに求めて算術平均し, 塩郷堰堤の 流域面積を乗じて実流量に変換すると, 平水 10.7 卜 ン, 低水 5.2 ト , 渴水 2.6 トンとなる。これらは下 泉測水所のデー夕と比べて，それぞれ $21 \%, 18 \%$, $16 \%$ でしかなく, 斉藤知事が勝ち取った 1 年のうち 261日（一年の $71 \%$ の時間）は 5 卜ン, それ以外は 3 トンという数字に近い.このことは, 仮に近い将来, 大井川から塩郷堰堤を撤去したとしても, 下流の大 井川に昭和 30 年代の水量を取り戻すことはできず, 
水量を取り戻したければ，上流ダム群を含めた総合 的な流量増加策を検討せざるを得ないことを意味し ている。

\section{5. 天地の流況}

天地測水所は，大井川の主要な支流である寸又川 に設けられた測水所である。流域面積は最上流の千 頭ダム $\left(132 \mathrm{~km}^{2}\right)$ よりも小さく，さらに上流に位置 するようであり，極めて自然度の高い河川である。

(社) 電力土木技術協会（1995）によれば，天地測 水所は1936（昭和11）年1月1日に開設され，測定義 務者は中部電力の前身である富士電力である。富士 電力は寸又川に発電所建設のため専用線（軌間 $762 \mathrm{~mm}$ ）を寸又川に沿って建設し，1929（昭和6）年 に沢間から湯山（千頭ダム）間が開通している。こ れが後の千頭森林鉄道であり，1968（昭和43）年に 廃止された。1941（昭和16）年には他の測水所と同 様，電力国家統制により日本発送電が測定義務者と なり，1951（昭和26）年5月1日より中部電力が引き 継いで現在に至っている.

天地測水所で観測された流況の長期変動を図一6 に示す。流況には田代, 井川の両測水所の流況にみ られた傾向がそのまま現れている。すなわち，1938 （昭和13）年及び1941（昭和16）年には豊水, 平水 流量が著しく多くなっており，この2つのピークに 挟まれた1939，40（昭和14～15）年には特に少ない. 1984（昭和59）年の豊水，平水流量も非常に少ない.

\section{6. 笹間川ダムの流況}

大井川下流で本流に合流し，上流には大きいダム がなく，比較的良好な自然状態が保たれている笹間 川を対象とし，笹間川ダム地点（流域面積 $68 \mathrm{~km}^{2}$ )

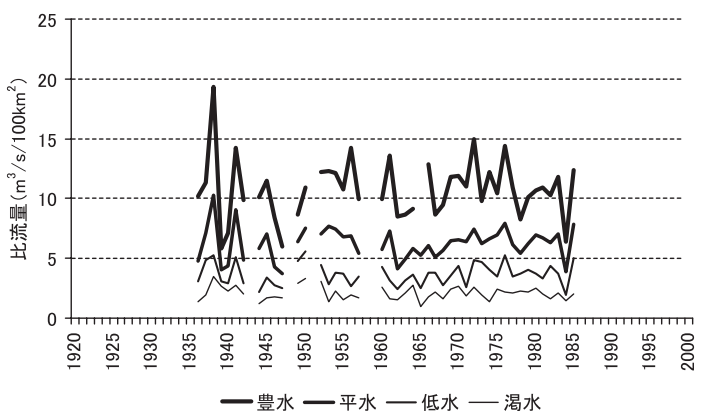

図-6 天地測水所における流況の長期変動

Fig.6 Long-term flow regime change in Tenchi.
で観測された笹間川の日流量データにより求めた流 況の長期変動を図一7に示す.1994（平成6）年は全 国的な渴水 (平6渴水) であり, 豊水流量が著しく落 ち込み, 豊水, 平水, 低水, 渴水流量はほぼ同じと なっているが，前後の年も含め，1992〜95 (平成4〜7) 年にかけて豊水，平水流量は例年より少なかったこと が読み取れる。一方，1990２000（平成2１2）年に かけて, 渇水流量は徐々に増加している。多ムのな い流域でのこのような変化は, 流域の森林の流量平 準化機能が森林の成長に伴い高まってきていること と関係がある可能性もあるが, 詳しくは今後の研究 に待つところが大きい.

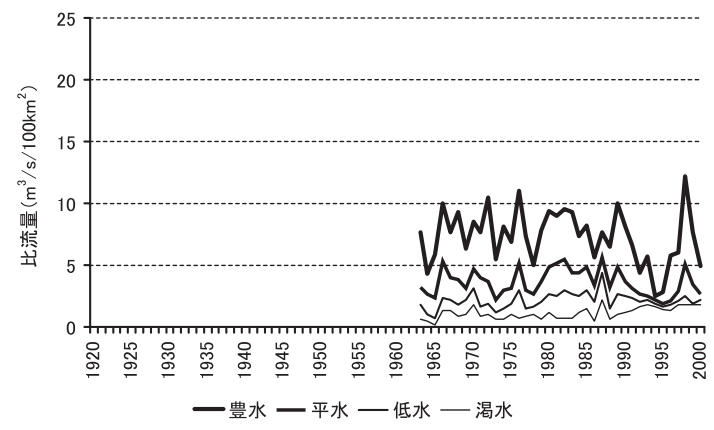

図-7 笹間川ダムにおける流況の長期変動

Fig.7 Long-term flow regime change in Sasamagawa Dam.

\section{7. 流況と流域面積の関係}

ここまで解析の対象としてきた，塩郷堰堤を除く 6地点については，ダムの影響がほとんどないデー 夕で構成されているため, 大井川にもしダムがな かったならばどのような水が流れるのかを明らかに することができると考えられる。そこで流況と流域 面積の関係を調べた。

豊水, 平水, 低水, 渇水流量の長期平均と流域面 積との関係を図一8に示す。データの期間は各地点 で異なるため，厳密には相互比較はできないが，時 系列デー夕の年々変動が小さいので, 平均を取る期 間が異なっていても，抒おまかな相互比較が可能で あると仮定して論を進める。

図一8に示された豊水，平水，低水，渇水流量の 長期平均と流域面積から, 大井川では基本的に豊水, 平水, 低水, 渇水比流量は流域面積にかかわらずほ ぼ一定であることがわかる，流域面積が小さい流域 では，ばらつきがみられるが，これは一般的に見ら れる傾向である。笹間川 $\left(68 \mathrm{~km}^{2}\right)$ の比流量は天地 


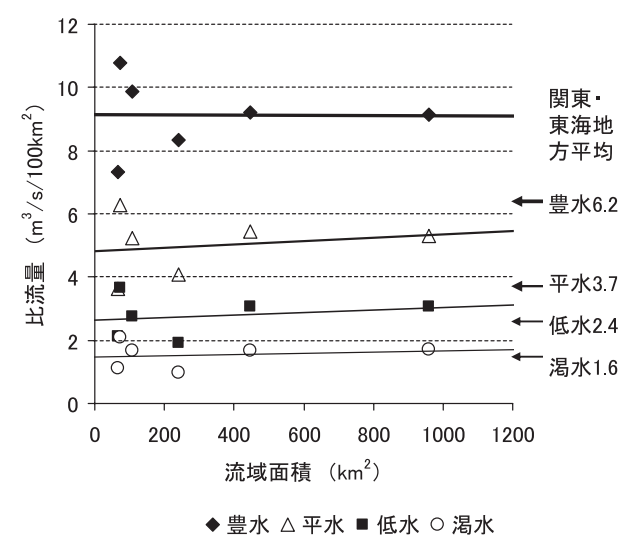

図 -8 豊水, 平水, 低水, 渇水比流量と流域面積の関係 直線は線形回帰直線

Fig.8 Relationship between flow regime and watershed area.

（73.4 km²）に比べて小さいが，これは笹間川が大井 川の下流に位置し降水量が若干少ないのに対して, 天地の位置する寸又川最上流部は降雨量が最も多い 地域であるためと推察される。流域面積が大きくな ると，そのような降雨や地形地質の空間的ばらつき が平均化されていき，ばらつきが小さくなる。井川 $\left(447 \mathrm{~km}^{2}\right)$ と下泉 $\left(959 \mathrm{~km}^{2}\right)$ は, 流域面積が約2倍 異なるにもかかわらず，流況にほとんど差がないの は興味深い。

ここで示された大井川の流況は, 日本の他の河川 と比べて明らかに大きくなっている。虫明ら（1981） は，日本の測水所のデー夕を整理し，気候区分別・ 地質別の長期平均流況を示しているが，そこで示さ れた関東・東海地方の平均比流量は, 豊水 6.2 , 平 水 3.7 , 低水 2.4 , 渴水 1.6 (流域面積 $100 \mathrm{~km}^{2}$ あたり比 流量）であり，図一8に示された值と比べると，大 井川の值はいずれも関東・東海地域平均をかなり上 回っていることがわかる.ささらにこれらの平均值は, 流域面積 $500 \mathrm{~km}^{2}$ 未満の山地河川について求められ たものであるが, 大井川においては流域面積 $1,000 \mathrm{~km}^{2}$ (下流域) でも依然としてこの平均值を上 回る流量があることを図一8は示している。一般的 に流域面積が大きい下流の地点ほど，降水量の減少 や農業用水の取水などにより, 比流量が減少するこ とを考えると, 大井川下流の流量の豊富さは特筆す べき点である.

ダム群ができる前の大井川が，いかに水量が豊富 な川であったかを，これらのデー夕は明瞭に示して いる.

\section{N 、おわりに}

大井川上流から下流および支流に位置する5地点 の測水所で観測された長期流況データについて検討 した。 その結果, 豊水, 平水流量が著しく多い年や 逆に少ない年は, 大井川流域全体で同期しているこ とがわかった。下泉測水所（塩郷堰堤）では, 現在 設定されている放流量に対して, 堰堤建設前には豊 かな水が流れていたことが定量的に示された。

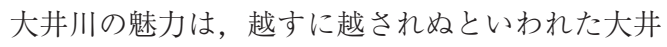
川の豊富な水量であることは間違いない。しかし川 の水が失われてすでに50年近くが経過し, 本稿で明 らかにされた「生きた大井川の姿」は, もはや年配 者の記憶の中にしか残っていない. 今の大井川流域 住民は死んだ大井川の姿しか知らず，それが当たり 前になっている。ささらに, 本稿では触れなかったが, 多数のダムや堰堤で土砂をせき止めた結果, 河川の 流送土砂量が減少し, 下流域の河床低下, 沿岸域の 海岸浸食, 内水面漁業や沿岸漁業の衰退, ウミガメ の産卵場所喪失など，多大な負の影響をもたらして いることが指摘されている。

自然と調和した，生きた大井川を今後新たに創り 出してゆくために，いま我々は何をすべきなのか. まずは現状の水利権を前提とした場合，その制約条 件の中で流況をどの程度回復することが可能なのか を科学技術的に検討することが必要である。また 2018～19（平成30～31）年に多くの岀の水利権の 更新時期がやってくることを見据えつつ, 問題解決 に向かって流域住民, 研究者, 県, 市町村, 民間企 業が一体となって考えてゆけるような仕組みを作っ てゆくことが必要とされている。

\section{謝辞}

平成 17 年度静岡県戦略課題研究「大井川 ·伊豆研 究会」を進めるにあたり, 静岡県企画部調整室政策 研究スタッフの皆様には献身的なご協力をいただい た。また現地踏査の際には筑波大学井川演習林 藤 岡正博助教授及び同演習林技術職員の皆様，大井川 の清流を守る研究協議会・大井川環境保全推進協議 会, 山田蔀氏, 大井川を再生する会, 生田八朗氏に ご協力いただいた．2名の査読者の方からは有益なご 指摘をいただいた。ここに記して感謝の意を表する。 


\section{参考文献}

天野礼子（2005）：だめダムが水害をつくる!?，講談社 $\alpha$ 新書, $185 \mathrm{pp}$.

電氣廳（1940）: 流量要覽, 第2回, 第一印刷所, 東京, 449pp. 岸原信義・石井正典（1982）：日本列島の山地流域からの流出 に関する研究 (I), 日林誌, 64, pp.373-381.

岸原信義・石井正典（1983）：日本列島の山地流域からの流出 に関する研究 (II), 日林誌, 65, pp.1-8.

国土庁土地局国土調査課（1988）：安倍川・大井川・菊川地域 主要水系調査書, $139 \mathrm{pp}$.

国土庁土地局国土調査課（1988）：安倍川・大井川・菊川地域 主要水系調査書 (資料編)，386pp.

蔵治光一郎 (2001) : 通商産業省による流量観測90年の歩み, 水文・水資源学会誌14巻1号, pp.83-89

虫明功臣・高橋裕・安藤義久 (1981)：日本の山地河川の流況 に及ぼす流域の地質の効果, 土木学会論文報告集, 309, pp.51-62.

大井川の清流を守る研究協議会・大井川環境保全推進協議会

(2004)：大井川通信 2004 Vol.1, 4pp.

社団法人電力土木技術協会 (1995) : 発電用河川流量調査85年 のあゆみ, 社団法人電力土木技術協会, 東京, $277 \mathrm{pp}$.

資源廳電力局（1950）：流量要覽（第3回），（財）商工會館出版 部, 東京, 468pp.

静岡地理教育研究会編（1989）：よみがえれ大井川 その変貌 と住民, 古今書院, 256pp.

田淵直樹（2002）：河川環境回復を求めた住民運動の政治過程 一大井川の「水返せ」運動を事例に一, 現代社会文化研究 No.23, 1-18pp.

遞信省電氣局 (1933) : 流量要覧, 530pp.

通商産業省公益事業局（1960）：発電水力調査書（第4次）流量

要覧, 発電水力協会, 東京, 457pp.

(受付：2006年7月11日，受理：2007年2月8日）

\title{
Flow Regime Change by Hydropower Dam in Oi River
}

\author{
Koichiro KURAJI 1) Jumpei MIZOGUCHI 1)2) \\ 1) University Forest in Aichi, Graduate School of Agricultural and Life Sciences, The University of Tokyo \\ (11-44 Goizuka, Seto, Aichi 489-0031, Japan ) \\ 2) River Policy Network \\ (1-21-11-3B Kita-horie, Nichi-ku, Osaka 550-0014, Japan)
}

In the Edo era, it was difficult for travelers in Tokai-do (the main road from Tokyo to Osaka) to pass through the Oi river because of the high water level and rapid flow. After the WWII, however, the river flow dramatically decreased due to hydropower dams developed throughout the river. As a result, the landscape of some parts in the downstream became called "river desert" because the wide river bed was covered by gravel without water. The aim of this study is to investigate flow regime changes from 1923 to 2000 to understand how much flow regime was changed in the past 80 years. It was found that before constructing the Shiogo Dam (before 1957), the normal, low, drought flow was $51.0,29.4,16.4 \mathrm{~m}^{3} / \mathrm{s}$ respectively. After constructing the Shiogo Dam (after 1963), the inflow of the dam were also reduced to $10.7,5.2,2.6 \mathrm{~m}^{3} / \mathrm{s}$ respectively. If people wish to restore the river flow regime in the Oi river, it will be not enough to remove the Shiogo Dam. An integrated river flow management is essential to restore the river flow regime in the past.

Key words : flow regime, Oi river, hydropower dam, river flow restoration, dam removal 